\title{
Explaining the Variation in the Europeanization of Business: an
}

\section{Institutionalist Theory.}

Matia Vannoni

\begin{abstract}
Although the EU provides valuable political opportunities for business, firms act at European level in different degrees and in different ways. This variation in the Europeanization of business has so far been partially overlooked by the literature. In this work I propose an institutionalist theory of the Europeanization of business by focusing on how national political institutions mediate the impact of the institutional structure of the EU on business behaviour. Findings from a large- $\mathrm{N}$ analysis across several countries demonstrate that firms in decentralized countries tend to be more active at EU level. National political institutions affect also how firms act at EU level. Indeed, those firms used to act individually at national level tend to act collectively at EU level. This work aims at a more nuanced institutionalist account of Europeanization, by bridging the gap between the traditional literature on comparative politics and the one on European interest representation.
\end{abstract}

KEY WORDS: business lobbying; European Union; Europeanization; federalism; multilevel governance.

\section{INTRODUCTION}

Why are certain firms more active at European level than others? Why do certain firms further their interests by addressing European institutions directly while others by acting through business associations? The mobility of interests, especially business interests, from a venue to another and their interest representation strategies represent questions of central importance for 
American and European scholars of interest group politics. On top of that, in the 1990s a strand of European studies started to investigate how and why national actors tend to assume similar behaviours when dealing with the European Union (EU), with the concept of Europeanization. Nonetheless, the literature has so far provided scattered pieces of evidence on the Europeanization of business: what determines the variation in Europeanization across firms is still waiting for an answer. In this work I introduce an institutionalist theory of the Europeanization of business by bridging the gap between two literatures which have contributed to the explanation of business behaviour in (rational choice) institutionalist terms: the literature on comparative politics and the literature on European interest representation.

This work proceeds as follows. I commence by arguing for an institutionalist approach to investigate the process of Europeanization. Although different scholarships have focused on the role national and European institutions exert on business behaviour I claim the need for further research on how national institutions mediate the effect of European institutions on business behaviour. In this vein, I outline the role national and European institutions exert on business behaviour, as proposed by the literature. In the ensuing section I introduce the institutionalist theory of Europeanization which unfolds that process into two theoretically and empirically separate mechanisms: the multilevel and the functional mechanisms. I derive hypotheses on the behaviour of business for those two mechanisms by building on the literature on comparative politics and the literature on European interest representation. Then, I conclude by showing the results of the analysis and underlining the implications those results bear.

\section{EXTANT INSTITUTIONALIST ACCOUNTS ON EUROPEANIZATION}

Although the literature on Europeanization agrees that the shift in competences from national arenas to European ones has drawn firms to the EU few theoretically and empirically informed 
claims able to account for this process have been put forward. Indeed, the soft spoken assumption in the traditional works on Europeanization has hitherto been that the process of the Europeanization of business is rather straightforward and thus does not require further investigation. The main determinant of the Europeanization of firms is argued to be material resources. This explains the paucity of works dealing specifically with business. Nonetheless, the high variation in the degree and mode of Europeanization across firms suggests that the Europeanization of business deserves further inquiry.

The strand of the literature on Europeanization which focuses on how and why interest groups engage at the European level from an organizational perspective (Beyers 2002; Beyers and Kerremans 2012; Klüver 2010; Eising 2007) points at the right direction. As argued by Beyers and Kerremans (2007), societal actors do not automatically shift from the national to the European level: 'although the EU creates many new opportunities for domestic groups to adapt, Europeanization is not a natural or immediate response' (Beyers and Kerremans 2007, 477). Rather, the different institutional contexts in which interest groups act mediate the process of Europeanization.

This (rational choice) institutionalist literature on the Europeanization of interest groups (Schmidt 2001; Risse, Cowles, and Caporaso 2001; Cowles 2001; Eising 2007; Klüver 2010) has so far put forward two main arguments: the goodness of fit and the degree of access (Klüver 2010). The goodness of fit claim states that societal actors based in national institutional settings similar to the European one tend to adapt better to the Europeanization process. The focus has been on the decentralization of power and the mode of interest representation: firms based in decentralized and (neo-)corporatist countries are deemed to adapt more easily to the EU institutional structure. Along with the goodness of fit, another major argument in the literature is 
the degree of access (Klüver 2010; Eising 2007). Interest groups with limited access at national level tend to be excluded also at European level (the persistence hypothesis) or to compensate for that limited access and hence to be more active at European level (the compensation hypothesis).

Nonetheless, contradictory findings have been drawn. Indeed, although Beyers (2002) finds general empirical support on the role of national institutional settings and Klüver (2010) demonstrates that French statist mode of interest representation incentivizes interest groups to be more proactive at EU level hence finding evidence for the compensation hypotheses other studies have come to different results. Eising (2007) concludes that the multi-level structure of the EU has more impact on interest groups' access to the EU than the different domestic institutional settings. Confusion on the role of national institutional settings on the Europeanization of societal actors prevails also in related fields of studies. From an interest population ecology perspective Wessels (2004) provides evidence that the relative fragmentation of interests at national level is proportional to the one at EU level. Nonetheless, this relationship reveals to be insignificant for business. In conclusion, although there is a general agreement on the necessity to account for how national institutional settings mediate the effect of Europeanization confusion still prevails on how to theoretically and empirically account for this process of mediation.

\section{THE INSTITUTIONAL THEORY OF EUROPEANIZATION: THE MULTILEVEL AND THE FUNCTIONAL MECHANISMS}

In this work I claim that the literature on the Europeanization of interest groups has so far oversimplified the role of European and national institutions: this explains the contradictory findings showed above. Indeed, the national and European levels are more than institutional contexts to be fitted or venues across which actors shop. Although those aspects are important 
(and hence investigated also in this work) institutions have a deeper influence on business behavior. The literature has so far overlooked the actual interest representation dynamics by focusing exclusively on access. Not only do national institutions mediate the push for Europeanization but they also incentivize certain forms of action on the part of firms and the same holds true for European institutions.

By bridging the gap between the literature on comparative politics and the one on European interest representation I introduce an institutionalist theory of Europeanization which investigates the adaptation of firms to the opportunity structure of the EU (Coen 2007b; Coen and Dannreuther 2003), as mediated by national political institutions. In doing so, I propose to unfold the process of Europeanization into two distinct mechanisms, namely the multilevel and the functional mechanisms. The former accounts for to what extent firms act at EU level and how this can be explained by the goodness of fit between the European and the national institutional settings. The functional mechanism refers to how firms act at EU level and it considers how national political institutions mediate the effect European institutions bear on interest representation.

\section{The Multilevel Mechanism}

The economic and political incentives for a firm to act at European level have almost come to balance those to act at national level and are arguably common to all firms. Nonetheless, the EU is also characterised by a distinct institutional structure which arguably facilitates the Europeanization of certain firms against others. By building on two mainstream comparative politics theories I derive an hypothesis on the role of national political institutions in mediating the effect of Europeanization: the federalism theory (Kelemen 2004) and the multilevel governance theory (Hooghe and Marks 2001; Marks 1996; Marks, Hooghe, and Blank 1996). 
In the last decades increasing attention has been devoted to the adaptational process societal actors undergo as a consequence of Europeanization (Börzel and Risse 2003). In the words of Börzel and Risse $(2003,2)$, 'from a rationalist perspective following the "logic of consequentialism", the misfit between European and domestic processes, policies, and institutions provides societal and/or political actors with new opportunities and constraints to pursue their interests'. In other words, the adaptational process which results from Europeanization bears differential effects on member states depending on their national political institutions. In this vein, two strands of the comparative politics literature can shed light on this process.

The literature on federalism has recently shifted the attention from the distribution of power to the logic of functioning of institutions (Burgess 2000; Fabbrini 2010; Kelemen 2004). As applied to the EU this shift of academic attention has led scholars to concentrate on how the logic of functioning of European institutions affects the relationship between the EU and member states. Indeed, the EU imposes not only regulatory standards in several policy domains but also policy styles to member states (Risse, Cowles, and Caporaso 2001). The multi-level governance theory on its part conceives the EU as a web of interconnected levels of governance where different types of actors interact with European institutions (Hooghe and Marks 2001). The focus in not on the top-down imposition of policy styles, as it is for the federalism theory, but on the horizontal and vertical relationships between different centres of informal governance (Peters 2008) where both European and national public and private actors interact with each other.

The MLG and the federalism theories arguably bear the same explanatory implication for the role of national institutions in the multilevel mechanism of Europeanization. Firms based in countries where authority is diffused both at horizontal and at vertical level, such as Germany, 
tend to adapt easily to the Europeanization process. Conversely, firms based in highly centralized countries, such as France, encounter more difficulties in adapting to that process. I formulate the following hypothesis:

H1: Firms based in decentralized countries are more likely to act at EU level

\section{The Functional Mechanism}

By bridging the gap between the traditional literature on comparative politics and the literature on European interest representation, I focus on an aspect of Europeanization so far overlooked by the literature, namely the functional mechanism. Not only does the EU incentivise firms to act at European level but it also incentivises specific interest representation dynamics. Indeed, the EU incentivises firms to act simultaneously through direct and collective action. Nonetheless, also national political institutions matter with respect to how firms act in the political arena.

One of the most valuable contributions to the unpacking of the relationship between European institutions and societal actors has been provided by the European literature on interest representation. Although being part of same discipline, the low level of cross-fertilization between the literature on the Europeanization of interest groups and the more general literature on EU interest representation is surprising. The argument is that the EU and especially the Commission have actively developed a distinct interest representation system with distinct norms and rules which in turn incentivize firms to act at EU level as well as certain behaviors on the part of firms. As a response to the increase in the number of interest groups and the widening of European competences in the 1990s, the EU started to shape the relations with interest groups in an active manner in order to maintain the flow of technical and reliable information on which EU officials rely on a daily basis. This strategy has been aimed to create a distinction between 
outsiders and insiders by utilising the incentive of non-policy benefits, such as the inclusion in the Commission's network of policy fora, committees and so on and so forth (Coen 2007b, 2009; Coen and Katsaitis 2013). In order to access this club interest groups have to adopt certain practices (Broscheid and Coen 2003), such as collaboration with other interests at EU level (Coen 2009, 2007a). This division between insiders and outsiders has been particularly marked in the relationship between European institutions and firms (Coen and Grant 2000). As a result, the European interest representation system has witnessed the emergence of common patterns of behaviour actively supported by European institutions.

The literature on European interest representation (Bouwen 2002, 2004; Chalmers 2011; Kluver 2011) demonstrates that certain interest representation practices are associated with certain functions (Michalowitz 2007) which in turn are associated with more or less access to the European institutions. The European Commission and the European Parliament grant access to credible and trustworthy firms which represent a genuinely European interest. In this vein, firms are incentivised to simultaneously put in practice individual and collective action practices in order to adapt to those institutional demands. Indeed, collective action at European level is associated by the literature to the representation of European interests (Bouwen 2002, 2004) whereas individual action is functionally associated with credibility (Michalowitz 2007). Accordingly, firms are arguably incentivised by European institutions to act both individually and collectively at EU level.

The literature on comparative politics on its part provides theoretically informed arguments on how political institutions shape business behaviour. By focusing on what have been labeled traditional institutions (Hall and Taylor 1996; March and Olsen 1984), such as the electoral system, comparative politics has investigated how the behavior of societal actors and, especially 
business, and their interaction with the public authority differ across countries (Berger, Hirschman, and Maier 1983; Lehmbruch 1984; Schmitter 1974, 1977; Schmitter and Lehmbruch 1979).

The electoral system, as argued by the traditional literature on comparative politics (Lijphart 1984; Lijphart 1977; Scharpf 1984) and by historical analyses on comparative political economy (Lawson and Merkl 1988; Maier 1984; Maier 1981), determines the mode of interaction between societal actors. This has been recently formalized by Martin and Swank (2008) and Martin and Swank (2012), who focus on the ease with which a firm can access the political agenda. In those countries with a majoritarian electoral system the access to the political agenda is easier and thus firms tend to act alone in the political arena. Conversely, in consensual countries access is hindered by the proportional electoral system thus incentivizing firms to collaborate among each other by acting outside the political arena. In arguing so, Martin and Swank (2008) provide theoretical foundation and empirical evidence to the claim that whilst countries with proportional electoral systems tend to be characterized by neocorporatist arrangements majoritarian countries by pluralist arrangements. Figure 1 illustrates the regression plot between the disproportionality of the electoral system and the degree of corporatism in European countries ${ }^{1}$. 


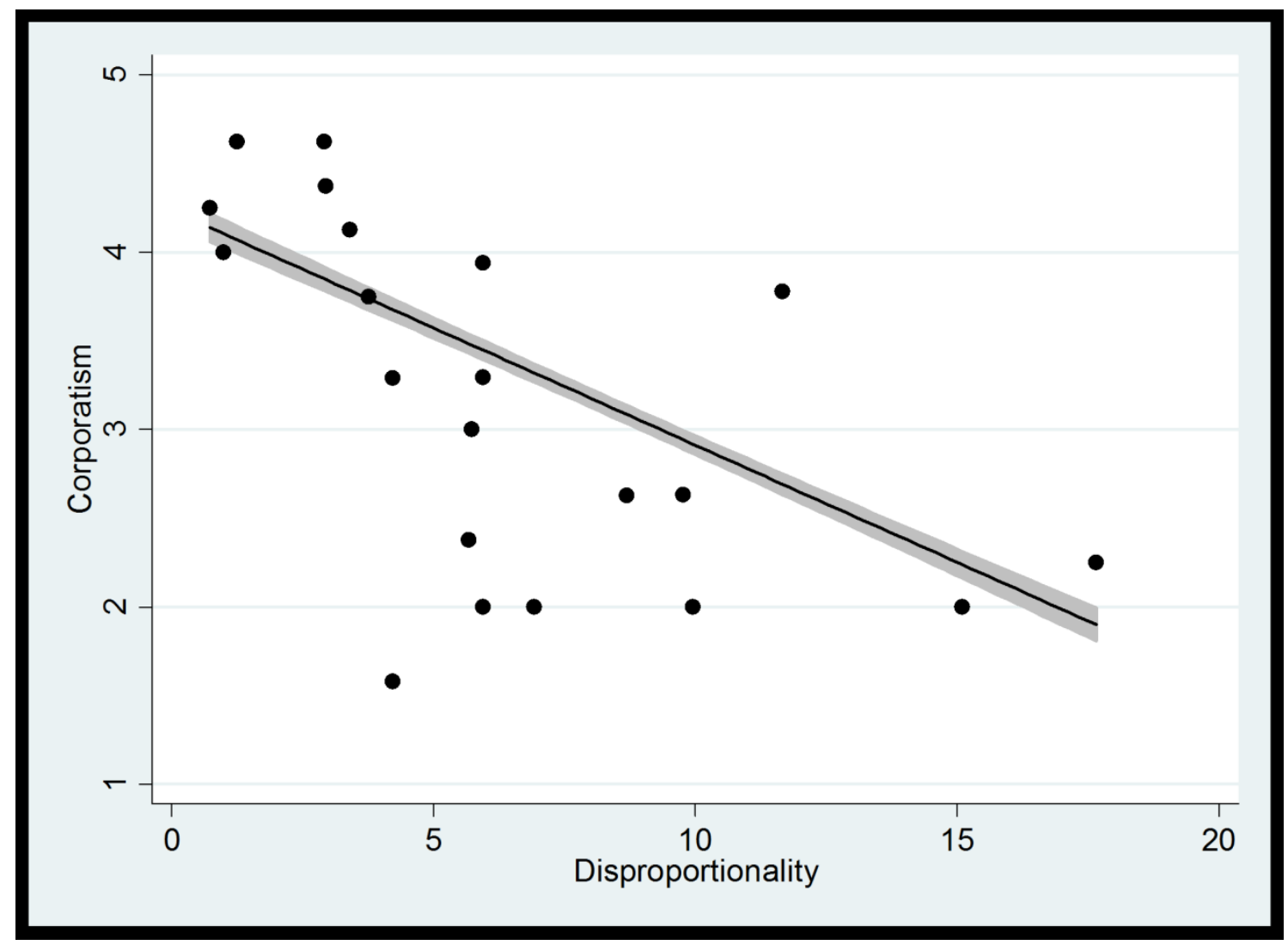

Figure 1 Regression Plot between the Disproportionality of the Electoral System and the Degree of Corporatism

In conclusion, European institutions incentivize the firm to adopt both collective and individual interest representation practices whereas national institutions incentivize firms to adopt either one or the other according to their character. In countries with majoritarian electoral systems and pluralist arrangements (what are labelled competitive countries) firms tend to act individually whereas in countries with proportional systems and neocorporatist arrangements (what are labelled consensual countries) the opposite holds true. Four hypotheses are drawn:

H2a: Firms based in competitive countries are more likely to act individually at EU level

H2b: Firms based in competitive countries are more likely to act collectively at EU level 
H3a: Firms based in consensual countries are more likely to act collectively at EU level

H3b: Firms based in consensual countries are more likely to act individually at EU level

The logic behind those hypotheses is close in spirit to the persistence and compensation hypotheses (Beyers 2002), familiar to the literature on the Europeanization of interests. Those hypotheses stem from the degree of access approach that literature has hitherto assumed (Eising 2007; Klüver 2010): they respectively argue that the more access an actor enjoy at domestic level and the more or the less it enjoys access at EU level. Nonetheless, the hypotheses put forward in this section refer to functional persistence and compensation and they focus on the actual interest representation dynamics. The former argues that the firm acts in the same manner both at national and EU level whilst the latter posits that the firm differentiates its lobbying portfolio pursuing different strategies across the two levels.

\section{DATA AND MEASUREMENT}

The dataset used in this work draws data from Wonka et al. $(2010)^{2}$. From that dataset I drew a sample consisting of all the 304 firms based in European member states present in the dataset ${ }^{3}$. Common practice in the literature is comparative case study research: large $\mathrm{N}$ analyses are rare in this field of study, but few notable exceptions (Eising 2007) are present. On top of that, almost all those works focus exclusively on the usual suspects: Germany, UK, France, Belgium and Netherlands. A sample with more variation in national political institutions as well as other factors is needed. For instance, the variation in the Europeanization of societal actors between old and new member states needs further investigation. 
The Europeanization of a firm needs to be operationalized in a different manner according to the mechanism under investigation. Indeed, the multilevel mechanism refers to the degree of Europeanization whereas the functional one to the different interest representation practices. For the multilevel mechanism I propose a composite index of whether a firm has a EU office and the membership in European associations whereas for the functional one I associate the former to individual action and the latter to collective action, as done in the literature (Bernhagen and Mitchell 2009). The coding of the composite index can be found in the Appendix (Table A1).

As for the functional mechanism, the literature on European interest representation demonstrates that European (business) associations are functional to represent European interests (Bouwen 2002, 2004; Michalowitz 2007). Similarly, Michalowitz (2007) functionally associates in-house lobbyists with credibility. This claim is also supported by a European affairs manager when questioned about the value added of a EU office with respect to other forms of interest representation in the poll conducted for this work: 'Close monitoring of policy developments and intellegence [intelligence] gathering in due time cannot be delegated. It depends on a network of trustful relations with key stakeholders, which in turn requires a permanent presence' (anonymous respondent 1, 2010 emphasis added) ${ }^{4}$.

As for the EU office, both the European affairs office in Brussels and in the headquarters are considered. Two sources are used. Data is gathered from the various EA booklets (EA 2006, 2007, 2008b, 2008a) $)^{5}$ and the Joint Transparency Register (JTR). Firms' involvement in European associations is measured with the number of European associations of which the firm is member: I collect data from the Joint Transparency Register (JTR) (CEC 2012a). The influence European institutions exert on business interest representation is operationalised into the access firms enjoy in the Commission and the European Parliament. Indeed, the more the 
firm enjoys direct access to the European institutions the more likely it is that the firm is subject to their influence. The access to the European Parliament is measured with the presence of a corporate representative for the European Parliament: data are collected from the Joint Transparency Register (JTR).

I use the membership of a firm in the Commission expert groups as operationalization for the access of firms to the Commission. The expert groups are consultative bodies established by the Commission or its services and their role is to advise the Commission (CEC 2010). They usually deal with highly technical sectors where EU officials most need specific expertise. Two aspects make these policy fora a valid operationalization of a form of access to the Commission suitable for this analysis. First of all, the Commission expert groups represent the largest information gathering system in the EU and they are located in one of the most neuralgic stage of the decision-making process, namely the pre-proposal stage. Secondly, the Commission expert groups arguably represent an example of the proactive role European institutions play in shaping interest representation mentioned above. The Commission has always enjoyed total discretion over both their composition and their creation (Gornitzka and Sverdrup 2013, 2008). Gornitzka and Sverdrup (2007) find empirical evidence for the relationship between the number of expert groups in a policy areas and the number of interest groups active in that policy area. This supports the claim that the expert group system is characterised by the phenomenon theorised by Broscheid and Coen (2003), namely the active use on the part of the Commission of non-policy benefits in order to regulate the inflow of information. I collect data for the membership of firms in those groups from the Register of the Commission Expert Groups and other Similar Entities (CEC 2012b). 
The two mechanisms theorised above take into consideration three national political institutions. The multilevel mechanism focuses on the level of decentralization of a country. This is measured with the Regional Authority Index (RAI) introduced by Hooghe, Marks, and Schakel (2008) ${ }^{6}$. That index combines a measure of the power enjoyed by a subnational authority in the country as a whole as well as over its own territory. The functional mechanism of Europeanization takes into consideration two correlated political institutions: the electoral system and the degree of corporatism. I use the Least Squares index (LSq), which measures disproportionality between the distributions of votes and of seats (Gallagher and Mitchell 2005), for the disproportionality of the electoral system. As for corporatism, I use the Siaroff index which measures the political and economic integration of societal actors and I collect data from the dataset provided by Bernhagen and Mitchell (2009).

I control for factors which the literature considers relevant for the Europeanization of firms. Building on both the American (Ozer and Lee 2009; Gilligan 1997; Alt et al. 1999) and the European (Bernhagen and Mitchell 2009) literature on business interest representation firm size deserves attention since it may influence the practices undertaken by firms. I operationalise firm size with the number of employees drawing data from AMADEUS (BvD 2013). Whether a firm (or its European branch) is based in a new or old member state may also affect the degree and form of Europeanization: I differentiate between those member states which joined the EU in the 2004 enlargement and those which were also before. A summary of the variables introduced in this section can be found in the Appendix (Table A2). 


\section{ANALYSIS}

Both individual and collective action practices are rather common across the firms in the sample. Indeed, roughly 60 per cent of the firms in the sample have an EU affairs office either in their headquarters or in Brussels and the average number of European associations in which a firm is a member is four, with some multi-national corporations being member in more than 20 European associations. European member states vary greatly with respect to political institutions. Indeed, the Regional Authority Index varies from 0 associated to Luxembourg, namely the most centralised member state, to the 29.3 of Germany. The same holds true for the electoral system and the degree of corporatism, which are closely related, as shown above. The sample goes from proportional and corporatist countries, such as Germany which scores respectively 3.4 and 4.125, to majoritarian and pluralist countries, such as the UK which scores respectively 15.1 and 2 .

I commence by testing the hypothesis related to the multilevel mechanism of Europeanization and then I proceed to testing the functional ones. Given that the 304 firms in this sample are clustered into 18 countries I fit a simple variance-components model, which estimates the variation accounted for by each level of the hierarchy, in order to test for the necessity of multilevel analysis. Findings show that 13 per cent of the variation in the dependent variable for the multilevel mechanism of Europeanization can be attributed to differences across countries. This suggests that multilevel analysis is needed. In this vein, I need to fit a random slope model which allows the explanatory variables to have a different effect for each group, namely a different slope and not only a different intercept, as in random intercept models. The model for the first analysis is as follows: 
EUIntegration $_{\mathrm{fc}}=\beta_{0}+\left(\beta_{1}+\mathrm{u}_{1 \mathrm{fc}}\right)\left(\right.$ Commission $\left._{\mathrm{fc}}\right)+\left(\beta_{2}+\mathrm{u}_{1 \mathrm{fc}}\right)\left(\mathrm{EP}_{\mathrm{fc}}\right)+\left(\beta_{3}+\mathrm{u}_{1 \mathrm{fc}}\right)\left(\right.$ Size $\left._{\mathrm{fc}}\right)+\left(\beta_{4}+\mathrm{u}_{1 \mathrm{c}}\right)$ $\left(\mathrm{Old} \mathrm{MS}_{\mathrm{c}}\right)+\left(\beta_{5}+\mathrm{u}_{1 \mathrm{c}}\right)\left(\mathrm{RAI}_{\mathrm{c}}\right)+\mathrm{u}_{0 \mathrm{c}}+\mathrm{e}_{\mathrm{fc}}$

The random slope model has two parts: a fixed part, represented by the intercept and the coefficient of the explanatory variable and a random part, namely $\mathrm{u}_{1 \mathrm{fc}}$, $\mathrm{u}_{0 \mathrm{c}}$ and $\mathrm{e}_{\mathrm{fc}}$. The element $\mathrm{u}_{0 \mathrm{c}}$ represents the unexplained variation at country level and $\mathrm{e}_{\mathrm{fc}}$ is the unexplained variation at firm level after controlling for the explanatory variables. As mentioned above, the slope for each independent variable varies across groups: for instance, $\beta_{1}$ represents the slope of the variable Commission averaged across groups to which variation for each group $\left(\mathrm{u}_{1 \mathrm{fc}}\right)$ is added.

Table 3 shows the results for the ordered logistic multilevel analysis for the variable Europeanization. The access of a firm to the Commission and the European Parliament is associated to the degree of Europeanization of that firm. As can be seen in Model 3, the coefficients of those variables are both statistically significant and take the values of 1.116 and 1.778. In this vein, European institutions affect business behaviour incentivising firms to take an active role at EU level. Similarly, the degree of decentralization of the country where the firm is based is associated with whether and to what extent the firm acts at EU level. The coefficient of the variable RAI is statistically significant and of the expected sign, namely 0.0291 (in Model 3). Accordingly, in more decentralised countries, such as Germany, the firm acts more at European level: this confirms $H 1$. In this vein, firms based in countries with a decentralized system similar to the European one tend to adapt more to the process of Europeanization. The size of a firm is also a determinant of its level of Europeanization, as foreseen by the literature. Indeed, larger and arguably more resourceful firms tend to be more active at EU level. Finally, whether a firm is based or not in an old member states does not affect the level of Europeanization. Surprisingly, 
although it would be reasonable to believe that firms based in old member states have more time to adapt to the process of Europeanization this does not find empirical evidence.

Table 3 Ordered Logistic Multilevel Analysis for Europeanization

\begin{tabular}{|c|c|c|c|}
\hline VARIABLES & Model 1 & Model 2 & Model 3 \\
\hline Commission & $\begin{array}{c}1.171 * * * \\
(0.359)\end{array}$ & $\begin{array}{c}1.154 * * * \\
(0.360)\end{array}$ & $\begin{array}{c}1.116 * * * \\
(0.362)\end{array}$ \\
\hline $\mathrm{EP}$ & $\begin{array}{c}1.727 * * * \\
(0.315)\end{array}$ & $\begin{array}{c}1.731 * * * \\
(0.316)\end{array}$ & $\begin{array}{c}1.778 * * * \\
(0.318)\end{array}$ \\
\hline Size & $\begin{array}{c}0.00665 * * * \\
(0.00169)\end{array}$ & $\begin{array}{c}0.00669 * * * \\
(0.00169)\end{array}$ & $\begin{array}{c}0.00653 * * * \\
(0.00171)\end{array}$ \\
\hline Old MS & & $\begin{array}{c}0.871 \\
(0.961)\end{array}$ & $\begin{array}{c}0.550 \\
(0.976)\end{array}$ \\
\hline RAI & & & $\begin{array}{l}0.0291 * \\
(0.0149)\end{array}$ \\
\hline Constant 1 & $\begin{array}{c}0.429 * * * \\
(0.157)\end{array}$ & $\begin{array}{c}1.286 \\
(0.960)\end{array}$ & $\begin{array}{c}1.516 \\
(0.968)\end{array}$ \\
\hline Constant 2 & $\begin{array}{c}0.464 * * * \\
(0.157)\end{array}$ & $\begin{array}{c}1.320 \\
(0.960)\end{array}$ & $\begin{array}{c}1.550 \\
(0.968)\end{array}$ \\
\hline Constant 3 & $\begin{array}{c}3.769 * * * \\
(0.318)\end{array}$ & $\begin{array}{c}4.632 * * * \\
(1.008)\end{array}$ & $\begin{array}{c}4.880 * * * \\
(1.018)\end{array}$ \\
\hline Observations & 304 & 304 & 304 \\
\hline Number of groups & 18 & 18 & 18 \\
\hline
\end{tabular}

Table 4 and 5 illustrate the testing of the functional theory of Europeanization. Table 4 shows the results for the linear multilevel analysis for the variable European association. Again, European institutions strongly affect firms' behaviour at EU level: the more a firm enjoys access to the Commission and the European Parliament and the more that firm is involved in European associations. As shown in Model 4 of Table 4, enjoying access to the Commission or the EP increases the number of European associations in which the firm is member respectively by 
2.786 or 2.5. As for national political institutions, no statistically significant relationship is found: neither the functional persistence nor the compensation hypotheses find empirical support. In other words, national political institutions do not affect a firm's collective action at EU level. In this case the impact of the European institutional structure is so strong that it thwarts the role of national political institutions. As above, also the size of the firm matters for whether the firm acts collectively at EU level but not whether it is based in an old member state.

Table 4 Linear Multilevel Analysis for European Association

\begin{tabular}{|c|c|c|c|c|}
\hline VARIABLES & Model 1 & Model 2 & Model 3 & Model 4 \\
\hline Commission & $\begin{array}{c}4.223 * * * \\
(0.710)\end{array}$ & $\begin{array}{c}2.846 * * * \\
(0.693)\end{array}$ & $\begin{array}{c}2.777 * * * \\
(0.697)\end{array}$ & $\begin{array}{c}2.786 * * * \\
(0.698)\end{array}$ \\
\hline EP & $\begin{array}{c}3.333 * * * \\
(0.591)\end{array}$ & $\begin{array}{c}2.472 * * * \\
(0.567)\end{array}$ & $\begin{array}{c}2.481 * * * \\
(0.568)\end{array}$ & $\begin{array}{c}2.500 * * * \\
(0.567)\end{array}$ \\
\hline Size & & $\begin{array}{c}0.0195 * * * \\
(0.00294)\end{array}$ & $\begin{array}{c}0.0197 * * * \\
(0.00294)\end{array}$ & $\begin{array}{c}0.0197 * * * \\
(0.00294)\end{array}$ \\
\hline Old MS & & $\begin{array}{c}1.995 \\
(1.798)\end{array}$ & $\begin{array}{c}1.874 \\
(2.009)\end{array}$ & $\begin{array}{c}1.935 \\
(2.010)\end{array}$ \\
\hline Disproportionality & & & $\begin{array}{l}-0.0360 \\
(0.0670)\end{array}$ & \\
\hline Corporatism & & & & $\begin{array}{c}0.187 \\
(0.331)\end{array}$ \\
\hline Constant & $\begin{array}{c}2.708 * * * \\
(0.308)\end{array}$ & $\begin{array}{c}-0.149 \\
(1.785)\end{array}$ & $\begin{array}{c}0.143 \\
(2.052)\end{array}$ & $\begin{array}{c}-0.721 \\
(2.249)\end{array}$ \\
\hline Observations & 304 & 304 & 304 & 304 \\
\hline Number of groups & 18 & 18 & 18 & 18 \\
\hline
\end{tabular}

Standard errors in parentheses $* * * \mathrm{p}<0.01, * * \mathrm{p}<0.05, * \mathrm{p}<0.1$ 
Table 5 Logistic Multilevel Analysis for the EU Office

\begin{tabular}{|c|c|c|c|c|}
\hline VARIABLES & Model 1 & Model 2 & Model 3 & Model 4 \\
\hline Commission & $\begin{array}{c}1.900 * * * \\
(0.668)\end{array}$ & $\begin{array}{c}2.077 * * \\
(0.885)\end{array}$ & $\begin{array}{c}2.064 * * \\
(0.976)\end{array}$ & $\begin{array}{c}2.148 * * \\
(1.046)\end{array}$ \\
\hline EP & $\begin{array}{c}2.484 * * * \\
(0.717)\end{array}$ & $\begin{array}{c}2.246 * * * \\
(0.646)\end{array}$ & $\begin{array}{c}2.389 * * * \\
(0.711)\end{array}$ & $\begin{array}{c}2.297 * * * \\
(0.661)\end{array}$ \\
\hline Size & & $\begin{array}{c}0.00992 * * * \\
(0.00292)\end{array}$ & $\begin{array}{c}0.0101 * * * \\
(0.00299)\end{array}$ & $\begin{array}{c}0.0101 * * * \\
(0.00298)\end{array}$ \\
\hline Old MS & & $\begin{array}{c}1.090 \\
(1.080)\end{array}$ & $\begin{array}{c}1.280 \\
(1.163)\end{array}$ & $\begin{array}{c}1.090 \\
(1.076)\end{array}$ \\
\hline Disproportionality & & & $\begin{array}{c}-0.0457 * * \\
(0.0210)\end{array}$ & \\
\hline Corporatism & & & & $\begin{array}{c}0.306 * * \\
(0.139)\end{array}$ \\
\hline Constant & $\begin{array}{l}-0.232 * \\
(0.124)\end{array}$ & $\begin{array}{l}-1.740 \\
(1.101)\end{array}$ & $\begin{array}{l}-1.543 \\
(1.178)\end{array}$ & $\begin{array}{c}-2.679 * * \\
(1.195)\end{array}$ \\
\hline Observations & 304 & 304 & 304 & 304 \\
\hline Number of groups & 18 & 18 & 18 & 18 \\
\hline
\end{tabular}

Table 5 illustrates the results of the logistic multilevel model for the variable EU office. As above, the access to European institutions is strongly related to the firm's behaviour: in this case the more the firm has access to those institutions and the more it pursues individual action at EU level. The odds of having a EU office for a firm with access to the Commission or the EP over those of a firm without access are respectively 5.84 and 6.24 (in Model 4). In other words, a firm with access to the European institutions (either the Commission or the EP) has roughly six times more chances to have a EU office than a firm without access (but similar in all other respects). The size of the firm is again significant and whether the firm is based in an old member state does not matter. The more interesting findings concern the role of national institutions. Empirical evidence supports the functional compensation hypothesis, namely $H 3 b$. Indeed, firms based in 
proportional and corporatist countries tend to act more individually at EU level. The coefficient for the variable Corporatism is significant and of the expected sign, namely 0.306 (in Model 4).

Before discussing further the results a consideration is due. Cross-sectional analysis often needs further scrutiny with respect to reverse causality and the latter is a particularly serious issue in Europeanization studies.. Beyers (2002), indeed, acknowledges the nuances of the analysis of Europeanization: 'another feature of multilevelness is that actors can be both subject and object of influence attempts by other actors' (p.595).Europeanization can be conceived as interactions with both institutions and other private interests. The researcher needs to take clear stances on which direction the relationship between access to European institutions and interest representation dynamics (comprising interaction with other actors) takes.

By building on the literature on European interest representation and more specifically on the interest overload argument (Broscheid and Coen 2003, 2007) I posit that the Commission shapes business behaviour through non-policy benefits, among which the membership in the Commission expert groups can be listed. As formally modelled in Broscheid and Coen (2003), the use of non-policy benefits in order to regulate the inflow of information from interest groups is theoretically and empirically prior to the change in behavior of interest groups, change which in this case is labelled Europeanization. In this vein, access to the Commission expert groups (as a proxy of the influence European institutions exert on societal actors) determines interest representation dynamics and not the other way round.

Nonetheless this issue bears also more practical implications. In more formal terms, in the regression model above the explanatory variable may be related to the unobserved factors affecting the dependent variable (Sovey and Green 2011). This can severely bias the analysis 
preventing thus the capacity to infer a causal relationship from the findings above. In this vein, I replace Commission fc $_{\text {with }}$ an instrumental variable (labelled Commission IV), which measures whether a firm has been awarded EU tendering contracts in the past ${ }^{7}$. This variable is related to Commission $_{\mathrm{fc}}$ but not to the unexplained variance in the model $\left(\mathrm{u}_{0 \mathrm{c}}+\mathrm{e}_{\mathrm{fc}}\right)$. In choosing such a variable, 'IV regression in effect replaces the problematic independent variable with a proxy variable that is uncontaminated by error or unobserved factors that affect the outcome' (Sovey and Green 2011, 188).

The award of tendering contracts in the EU depends exclusively on the economic value of the bids and whether they respect the technical standards set out in the call. Differently from the calls issued by national and local authorities which deal mainly with building and civil engineering (Cox and Furlong 1997) calls from EU institutions and agencies concern mainly highly technical services. Accordingly, firms with great technical expertise in their own sectors usually win those bids (Cox and Furlong 1997; Nielsen and Hansen 2001). The technical expertise of a firm in its own sector drives also the choice of who seats in the Commission expert groups. As mentioned above, Commission expert groups represent the largest suppliers of technical expertise for EU officials in various policy areas. Furthermore, the capacity to be awarded tendering contracts is not related to the unobservable factors affecting whether a firm acts at EU level and how it does so. Although it is plausible that interest representation dynamics affect access to the Commission it is not plausible that they affect the level of technical expertise of a firm in its own sector.

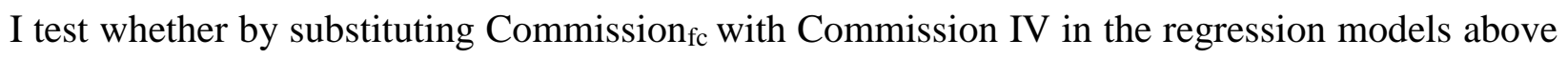
I obtain the same results. It should be noticed that for computational ease I do not use multilevel analysis but I cluster standard errors across countries. For reasons of space regression tables can 
be found in the Appendix (Table A3, A4, A5). The regression analyses show high Wald tests of exogeneity demonstrating that the assumption that the dependent and the instrumental variables are exogenous is valid. Results from the instrumental variable analysis do not differ with respect to the explanatory variables: this provides strong robustness to the results presented in this work. A puzzle is present: why is the functional compensation hypothesis valid only for individual action and not for collective action? An answer may be found in the different costs of Europeanization. Collective action at EU level in the form of membership to European association is less costly than individual action. In this vein, collective action may be conceived as soft budget-constraint form of Europeanization. Accordingly, regardless of how the firm acts in its own country it can afford to act at collective level at EU level. Conversely, individual action in the form of a permanent EU affairs office, for instance, is a hard budget-constraint form of Europeanization. In this case what Beyers and Kerremans (2007) term critical resource dependence applies: firms do not automatically translate their resources into interest representation at EU level and this holds true particularly for costly strategies.

In conclusion, I find evidence for the differentiation of firms' lobbying portfolio between national and European level, especially with respect to hard budget-constraint practices. Indeed, firms in corporatist countries differentiate their lobbying portfolio by acting individually at EU level, along with collectively at national level. Contrariwise, firms in pluralist countries already have government affairs and in house lobbyists at domestic level: creating new ones purposely for the EU level would be excessively costly. This rationale applies only to hard budgetconstraint forms of Europeanization and not, for instance, for collective action in the form of membership in European association, which is a rather inexpensive practice. I demonstrate that not only does the misfit between the national setting and the EU one affect the Europeanization 
of business, as already suggested by the literature, but also that the actual interest representation dynamics and their costs matter.

\section{CONCLUSION}

The institutionalist theory of the Europeanization of business interests provides an explanation for the variation in the degree of Europeanization as well as in the interest representation dynamics across firms. Indeed, the institutional structure of the EU exerts a strong influence on business behavior both in terms of whether firms act at EU level and in terms of their actual practices. This influence is, nonetheless, mediated by the role of national political institutions. Indeed, the degree of decentralization of a country affects the capacity of a firm to adapt to the European institutional architecture: firms based in decentralized countries tend to be more active at EU level. The functional mechanism of the institutionalist theory of the Europeanization of business interests provides a theoretically sound explanation for the role of national political institutions, such as the electoral system and the degree of corporatism. Nonetheless, the costs of different forms of Europeanization should also be taken into consideration.

The institutionalist approach embraced in this work is only the starting point in the hope that further research will be conducted in order to explain the variation in Europeanization across firms. The ontogenetic development of the literature on the Europeanization of business can be predicted by looking at the phylogenetic development of contemporary political science. Indeed, both of them started from a behaviorist perspective before adopting institutionalist premises. This is the state of the art in the literature on the Europeanization of business interests. Nonetheless, contemporary political science has already moved to investigate factors other than traditional institutions, such as culture, social norms etc. Future research should follow those 
steps and focus on the role management structures as well as business cultures, for instance, influence the process of Europeanization of business. 
Biographical note: Matia Vannoni is a PhD candidate at the School of Public Policy, University College London.

Address for correspondence: Matia Vannoni, School of Public Policy, UCL, 29 Tavistock Square, London, WC1H 9QU, UK. Email: m.vannoni.12@ucl.ac.uk

\section{ACKNOWLEDGEMENTS}

Preliminary drafts of this paper were presented at the 4th Biennial ECPR Standing Group for Regulatory Governance Conference, Exeter, 27-29 June 2012 and at the 9th University of Pittsburgh Graduate Student Conference on the European Union, Pittsburgh, 28 Febraury-1 March 2014. I am particularly grateful to the panellists and the audience for their comments and criticisms.

\section{NOTES}

${ }^{1}$ For data sources and operationalization of variables see below.

${ }^{2}$ This dataset maps the interest group population active at EU level by drawing data from three distinct sources: the CONECCS, the EP register and the Landmark directories.

${ }^{3}$ Data shows that almost all firms are involved in regulatory policies: health, agriculture, transport and energy. On top of that, common areas of interest among firms are present, such as competition or employment and social affairs. In this vein, it is not necessary to control for the sector in the analysis below.

${ }^{4}$ A survey was directed to 178 government and European affairs managers on 10 January 2012. Contacts were drawn from the 180 Company Representations in Brussels, European Agenda Booklet (EA, 2007). The survey consisted mainly of ordinal scale questions along with few open questions. 
${ }^{5}$ EA booklets are publicly available EU public affairs directories which map the main actors at the EU level as well as they supply their contact details.

${ }^{6}$ http://www.unc.edu/ gwmarks/data_ra.php.

${ }^{7}$ Data was drawn from the JTR under the entry Financial Data.

\section{REFERENCES}

Alt, J.E., Carlsen, F., Heum, P., and Johansen, K. (1999) 'Asset Specificity and the Political Behaviour of Firms: Lobbying for Subsidies in Norway'. International Organization 53(1):99-116.

Berger, S., Hirschman, A., and Maier, C. (1983) Organizing Interests in Western Europe: Pluralism, Corporatism, and the Transformation of Politics, Cambridge: Cambridge University Press.

Bernhagen, P. and Mitchell, N.J. (2009) 'The Determinants of Direct Corporate Lobbying in the European Union'. European Union Politics 10(2):155-76.

Beyers, J. (2002) 'Gaining and seeking access: The European adaptation of domestic interest associations'. European Journal of Political Research 41(5):585-612.

Beyers, J. and Kerremans, B. (2007) 'Critical Resource Dependencies and the Europeanization of Domestic Interest Groups'. Journal of European Public Policy 14 (3):460-81.

Beyers, J. and Kerremans, B. (2012) 'Domestic embeddedness and the dynamics of multilevel venue shopping in four EU member states'. Governance 25(2):263-90.

Börzel, T.A. and Risse, T. (2003) 'Conceptualizing the domestic impact of Europe', in K. Featherstone and C.M. Radaelli (ed.), The politics of Europeanization. Oxford: Oxford University Press, pp. 57-80. 
Bouwen, P. (2002) 'Corporate lobbying in the European Union: the logic of access'. Journal of European Public Policy 9(3):365-90.

Bouwen, P. (2004) 'Exchanging access goods for access: A comparative study of business lobbying in the European Union institutions'. European Journal of Political Research 43(3):337-69.

Broscheid, A. and Coen, D. (2003) 'Insider and Outsider Lobbying of the European Commission: An Informational Model of Forum Politics'. European Union Politics 4(2):165-89.

Broscheid, A. and Coen, D. (2007) 'Lobbying activity and fora creation in the EU: empirically exploring the nature of the policy good'. Journal of European Public Policy 14(3):34665.

Burgess, M. (2000) Federalism and European Union: The Building of Europe, 1950-2000, London: Routledge.

BvD, B.V.D. (2013) AMADEUS. http://www.bvdinfo.com.

CEC (2010) 'Framework for Commission Expert Groups: Horizontal Rules and Public Register ', $C(2010)$ 7649, Brussels: European Commission.

$\begin{array}{lllll}\text { CEC (2012a) Joint } & \text { Transparency }\end{array}$ http://ec.europa.eu/transparencyregister/info/homePage.do.

CEC (2012b) Register of the Commission Expert Groups and other Similar Entities. http://ec.europa.eu/transparency/regexpert/.

Chalmers, A.W. (2011) 'Interests, Influence and Information: Comparing the Influence of Interest Groups in the European Union'. Journal of European Integration 33(4):471-86.

Coen, D. (2007a) 'Empirical and theoretical studies in EU lobbying'. Journal of European Public Policy 14(3):333-45. 
Coen, D. (2007b) 'Lobbying in the European Union', PE 393.266, Brussels: European Parliament.

Coen, D. (2009) 'Business Lobbying in the European Union', in D. Coen and J. Richardson (ed.), Lobbying the European Union: Institutions, Actors and Issues. Oxford: Oxford University Press, pp. 145-68.

Coen, D. and Dannreuther, C. (2003) 'Differentiated Europeanization: Large and Small Firms in the EU Policy Process', in K. Featherstone and C.M. Radaelli (ed.), The politics of Europeanization. Oxford: Oxford University Press, pp. 255-75.

Coen, D. and Grant, W. (2000) 'Corporate Political Strategy and Global Policy: A Case Study of the Transatlantic Business Dialogue'. European Business Journal 13(1):37 - 44.

Coen, D. and Katsaitis, A. (2013) 'Chameleon pluralism in the EU: an empirical study of the European Commission interest group density and diversity across policy domains'. Journal of European Public Policy 20(8):1104-19.

Cowles, M. (2001) 'The Transatlantic Business Dialogue and Domestic Business- Government Relations', in M.G. Cowles, J.A. Caporaso and T. Risse (ed.), Transforming Europe. Europeanization and Domestic Change. Ithaca: Cornell University Press, pp. 159-79.

Cox, A. and Furlong, P. (1997) 'Cross-border trade and contract awards The intellectual myopia at the heart of the EU procurement rules'. European Journal of Purchasing \& Supply Management 3(1):9-20.

EA (2006) '75 Energy Associations, Companies, Consultancies and Institutions', Brussels: Helios Media sprl.

EA (2007) '180 Company Representations in Brussels', Brussels: Helios Media sprl. 
EA (2008a) '93 Transport Associations, Companies and Institutions', Brussels: Helios Media sprl.

EA (2008b) '156 IT and Telecommunication Associations, Companies and Institutions', Brussels: Helios Media sprl.

Eising, R. (2007) 'Institutional context, organizational resources and strategic choices explaining interest group access in the European Union'. European Union Politics 8(3):329-62.

Fabbrini, S. (2010) Compound Democracies: Why the United States and Europe Are Becoming Similar, Oxford: Oxford University Press.

Gallagher, M. and Mitchell, P. (2005) The Politics of Electoral Systems, Oxford: Oxford University Press.

Gilligan, M. (1997) 'Lobbying as a Private Good with Intra-Industry Trade'. International Studies Quarterly 41:455-74.

Gornitzka, A. and Sverdrup, U. (2007) 'Who Consults? Expert Groups in the European Union'. ARENA Working Paper 12.

Gornitzka, Å. and Sverdrup, U. (2008) 'Who Consults? The Configuration of Expert Groups in the European Union'. West European Politics 31(4):725-50.

Gornitzka, Å. and Sverdrup, U. (2013) 'Societal Inclusion’ In Expert Venues - A Note On The Participation Of Interest Groups And Corporate Actors In Eu Policy Making', EPISTO workshop, April 2013.

Hall, P.A. and Taylor, R.C.R. (1996) 'Political Science and the Three New Institutionalisms'. Political Studies 44(5):936-57.

Hooghe, L. and Marks, G. (2001) Multi-level Governance and European Integration, Lanham: Rowman \& Littlefield Publishers. 
Hooghe, L., Marks, G., and Schakel, A.H. (2008) 'Regional Authority in 42 Democracies, 19502006. A Measure and Five Hypotheses'. Regional and Federal Studies 18(2-3):111-302.

Kelemen, R.D. (2004) The Rules of Federalism, Cambridge: Harvard University Press.

Kluver, H. (2011) 'The contextual nature of lobbying: Explaining lobbying success in the European Union'. European Union Politics 12(4):483-506.

Klüver, H. (2010) 'Europeanization of Lobbying Activities: When National Interest Groups Spill Over to the European Level'. Journal of European Integration 32(2):175-91.

Lawson, K. and Merkl, P. (1988) When Parties Fail, Princeton: Princeton University Press.

Lehmbruch, G. (1984) 'Concertation and the Structure of Corporatist Networks', in J.H. Goldthorpe (ed.), Order and conflict in contemporary capitalism. Oxford: Clarendon Press, pp. 60-80.

Lijphart, A. (1977) Democracy in Plural Societies: A Comparative Exploration, New Haven: Yale University Press.

Lijphart, A. (1984) Democracies: Patterns of Majoritarian and Consensus Government in Twenty-One Countries, New Haven: Yale University Press.

Maier, C. (1984) 'Preconditions for Corporatism', in J.H. Goldthorpe (ed.), Order and Conflict in Contemporary Capitalism. Oxford: Clarendon Press, pp. 39-59.

Maier, C.S. (1981) 'Fictitious bonds... of wealth and law: on the theory and practice of interest representation', in S. Berger (ed.), Organizing interests in Western Europe : pluralism, corporatism, and the transformation of politics. Cambridge: Cambridge University Press, pp.225-260.

March, J.G. and Olsen, J.P. (1984) 'The New Institutionalism: Organizational Factors in Political Life'. The American Political Science Review 78(3):734-49. 
Marks, G. (1996) 'An actor-centred approach to multi-level governance'. Regional \& Federal Studies 6(2):20-38.

Marks, G., Hooghe, L., and Blank, K. (1996) 'European Integration from the 1980s: StateCentric v. Multi-level Governance'. JCMS: Journal of Common Market Studies 34(3):341-78

Martin, C.J. and Swank, D. (2008) 'The Political Origins of Coordinated Capitalism: Business Organizations, Party Systems, and State Structure in the Age of Innocence'. American Political Science Review 102(02):181-98.

Martin, C.J. and Swank, D. (2012) The Political Construction of Business Interests: Coordination, Growth, and Equality, Cambridge Cambridge University Press.

Michalowitz, I. (2007) 'What determines influence? Assessing conditions for decision-making influence of interest groups in the EU'. Journal of European Public Policy 14(1):132-51.

Nielsen, J.-M. and Hansen, L. (2001) 'The EU public procurement regime- Does it work?'. Intereconomics 36(5):255-63.

Ozer, M. and Lee, S.-H. (2009) 'When Do Firms Prefer Individual Action to Collective Action in The Pursuit of Corporate Political Strategy? A New Perspective on Industry Concentration'. Business and Politics 11(1):1-21.

Peters, G. (2008) 'Forms of informal governance: searching for efficiency and democracy', in T. Christiansen and T. Larsson (ed.), The Role of Committees in the Policy-Process of the European Union. Cheltenham: Edward Elgar, pp. 39-63.

Risse, T., Cowles, M., and Caporaso, J. (2001) 'Europeanization and domestic change: introduction', in J.C. M. G. Cowles, \& T. Risse (ed.), Transforming Europe. Ithaca: Cornell University Press, pp. 1-20. 
Scharpf, F.W. (1984) 'Economic and Institutional Constraints of Full-Employment Strategies: Sweden, Austria, and Western Germany, 1973-1982', in J. Goldthorpe (ed.), Order and Conflict in Contemporary Capitalism. Oxford: Clarendon pp. 257-90.

Schmidt, V.A. (2001) 'The politics of economic adjustment in France and Britain: when does discourse matter?'. Journal of European Public Policy 8(2):247-64.

Schmitter, P.C. (1974) 'Still the Century of Corporatism?'. The Review of Politics 36(1):85-131.

Schmitter, P.C. (1977) 'Modes of Interest Intermediation and Models of Societal Change in Western Europe'. Comparative Political Studies 10(1):7-38.

Schmitter, P.C. and Lehmbruch, G. (1979) Trends toward corporatist intermediation, London: Sage Publications.

Sovey, A.J. and Green, D.P. (2011) 'Instrumental Variables Estimation in Political Science: A Readers' Guide'. American Journal of Political Science 55(1):188-200.

Wessels, B. (2004) 'Contestation potential of interest groups in the EU: emergence, structure, and political alliances', in G. Marks and M.R. Steenbergen (ed.), European Integration and Political Conflict. Cambridge: Cambridge Universoty Press, pp. 195-215.

Wonka, A., Baumgartner, F.R., Mahoney, C., and Berkhout, J. (2010) 'Measuring the size and scope of the EU interest group population'. European Union Politics 11(3):463-76. 